\title{
PENGARUH BEBAN OPERASIONAL PENDAPATAN OPERASIONAL (BOPO), NON PERFORMING FINANCING, DAN UKURAN PERUSAHAAN TERHADAP TINGKAT EFISIENSI PERBANKAN SYARIAH DI INDONESIA
}

\author{
Rizka Fauzi ${ }^{1}$, Rulfah M. Daud ${ }^{* 2}$ \\ ${ }^{1,2}$ Program Studi Akuntansi Fakultas Ekonomi Universitas Syiah Kuala \\ e-mail: rizkaffauzi97@gmail.com ${ }^{1}$, rulfahm.daud@unsyiah.ac.id ${ }^{* 2}$ \\ * Corresponding Author
}

\begin{abstract}
This research aims to investigate the influence of BOPO, Non Performing Financing, and Firm Size on Efficiency Level of Islamic Banking in Indonesia. The efficiency score is obtained using Data Envelopment Analysis (DEA) Method. The type of data employed is secondary data from financial statements of each banks between 2014 and 2018. The results of this research indicate that (1) Operating Expenses against Operating Income, Non Performing Financing, and Firm Size simultaneously affect the efficiency level, (2) Operating Expenses against Operating Income does not affect the efficiency level, (3) Non Performing Financing does not affect the efficiency level, and (4) Firm Size affects the efficiency level of islamic banking in Indonesia
\end{abstract}

Keywords: Efficiency, Data Envelopment Analysis, Indonesian Islamic Banking

\section{Pendahuluan}

Berdasarkan Undang-Undang Republik Indonesia nomor 10 tahun 1998 tanggal 10 November 1998 mengenai perbankan, yang dimaksud dengan bank yaitu "suatu badan usaha yang menghimpun dana dari masyarakat dalam bentuk simpanan dan menyalurkannya kepada masyarakat dalam bentuk kredit dan bentuk lainnya dalam rangka meningkatkan kualitas taraf hidup orang banyak". Terdapat dua jenis perbankan yang beroperasi di Indonesia, yaitu bank yang melakukan kegiatan usaha berdasarkan prinsip bunga yang disebut dengan bank konvensional dan bank yang melakukan kegiatan usaha berdasarkan prinsip bagi hasil yang disebut dengan bank syariah. Keberadaan bank konvensional telah lebih dulu ada dibandingkan dengan bank syariah, sehingga bank konvensional lebih mampu menguasai pasar perbankan nasional dengan jumlah kantor yang lebih banyak dan aset yang lebih besar pula tentunya. Akan tetapi seiring dengan perkembangannya, dunia perbankan syariah khususnya perbankan syariah di Indonesia mengalami kemajuan yang pesat (Amalia dan Fitri, 2018).

Pesatnya perkembangan industri perbankan syariah di Indonesia semakin menuntut adanya pengukuran mengenai tingkat efisiensi bank syariah.

Pengukuran tingkat efisiensi dalam industri perbankan syariah menjadi sesuatu yang penting dengan melihat ketatnya persaingan dalam industri perbankan syariah. Semakin efisien industri perbankan, maka akan semakin baik kinerjanya, begitu pula sebaliknya (Hidayat, 2011).

Muharam dan Nugroho (2009) menyatakan bahwa Salah satu metode untuk menghitung efisiensi adalah Data Envelopment Analysis (DEA). DEA menghitung nilai efisiensi untuk seluruh unit bank- bank syariah. DEA merupakan prosedur yang dirancang khusus untuk mengukur nilai efisiensi yang menggunakan banyak input dan banyak output, dimana penggabungan input dan output tersebut tidak dapat dilakukan.

Berdasarkan penelitian sebelumnya, ditemukan beberapa faktor yang dapat mempengaruhi tingkat efisiensi perbankan syariah. Abdullah, (2003) menyatakan bahwa BOPO yang tinggi menunjukkan kurangnya efisien bank dalam menjalankan kegiatan operasionalnya karena biaya operasional yang harus ditanggung lebih besar daripada pendapatan 
operasional yang diperoleh sehingga ada kemungkinan modal digunakan untuk menutupi biaya operasional yang tidak tertutup oleh pendapatan operasional.

Sebelumnya, penelitian yang dilakukan oleh Nurwulan (2011) yang menyimpulkan bahwa NPF berpengaruh positif terhadap tingkat efisiensi perbankan. Apabila bank tidak mampu mengelola pinjaman atau pembiayaan maka akan berpengaruh terhadap NPF yang nantinya akan berpengaruh terhadap tingkat efisiensi.

Penelitian lain yang dilakukan Fafa Yushifa (2015) menyatakan bahwa ukuran perusahaan berpengaruh secara positif dan tidak memiliki pengaruh yang signifikan terhadap tingkat efisiensi bank syariah. Ukuran perbankan yang lebih besar dan memiliki keunggulan salah satunya modal yang lebih besar tentunya relatif akan menghasilkan profit yang lebih besar pula, dimana nantinya tingkat profitabilitas ini akan berpengaruh terhadap tingkat efisiensi suatu perbankan.

Tujuan dari penelitian ini adalah untuk menguji pengaruh BOPO, Non Performing Financing, dan ukuran perusahaan baik secara bersama-sama maupun secara parsial terhadap tingkat efisiensi perbankan syariah. Penelitian ini diawali dengan menjelaskan beberapa kajian kepustakaan yangrelevan dengan penelitian dan metode penelitian yang digunakan, kemudian dilanjutkan dengan membahashasil pengujian hipotesis serta diakhiri dengan mengambil beberapa kesimpulan dari hasil penelitian.

\section{Kajian Pustaka}

\section{Teori Efisiensi}

Menurut Hidayat (2011) Efisiensi merupakan nisbah atau rasio antara output dan input, perusahaan termasuk perbankan dapat dikatakan efisien apabila mampu menghasilkan output yang lebih banyak dibanding input yang dikeluarkan atau dapat menghasilkan output yang sama tetapi input yang dikeluarkan lebih. (Muharram dan Pusvitasi, 2005) menyatakan jika Sebuah perbankan yang kurang efisien secara umum diakibatkan oleh tiga hal yaitu: terdapatnya rantai birokrasi yang berkepanjangan, alokasi yang salah dalam penggunaan sumber daya yang ada, serta tidak terdapatnya economics of scale.

\section{Beban Operasional Pendapatan \\ Operasional (BOPO)}

Menurut (Lukman Dendawijaya 2009:119) BOPO didapat dari rasio perbandingan antara beban operasional dengan pendapatan operasional. Rasio ini digunakan untuk mengukur kemampuan manajemen bank dalam mengendalikan biaya operasional terhadap pendapatan operasional. Semakin kecil rasio ini berarti semakin efisiensi biaya operasional bank dalam menjalankan operasi seharihari, sehingga kemungkinan suatu bank dalam kondisi bermasalah semakin kecil.

BOPO ialah perbandingan antara biaya yang dikeluarkan oleh bank dalam melakukan kegiatan utamanya terhadap pendapatan yang didapat dari kegiatan tersebut. Menurut Wiroso (2005:99) Bank syariah dalam aktivitas operasionalnya melakukan kegiatan mengumpulkan dan penyaluran dana. Kegiatan ini akan menjadikan kewajiban bagi bank untuk memberikan insentif bagi hasil kepada deposan, sedangkan kegiatan penyaluran dana akan menjadi sumber pendapatan bagi bank syariah.

\section{Non Performing Financing}

Non Performing Financing (NPF) adalah rasio antara pembiayaan yang bermasalah dengan total pembiayaan yang disalurkan oleh bank syariah berdasarkan kriteria yang sudah ditetapkan oleh Bank Indonesia. Kategori yang termasuk dalam NPF adalah pembiayaan kurang lancar, diragukan dan macet. Non Performing Financing (NPF) adalah suatu keadaan dimana nasabah sudah tidak sanggup lagi membayar sebagian atau seluruh kewajibannya kepada pihak bank seperti yang telah diperjanjikan di awal (Mudrajat dan Suharjonoo,2002).

Menurut Mahmoedin (2010) dalam bukunya menyebutkan bahwa :suatu pembiayaan yang mengalami masalah biasanya dikarenakan oleh faktor eksternal pihak nasabah maupun internal dari bank itu sendiri Faktor-faktor internal diantaranya meliputi kebijakan dari pihak bank dalam pemberian pembiayaan yang terlalu ekspansif,lemahnya sistem administrasi dan pengawasan pembiayaan,serta lemahnya sistem informasi pembiayaan. Sedangkan untuk faktor eksternal penyebabnya adalah kegagalan usaha 
debitor,menurunnya kegiatan ekonomi dan musibah yang terjadi pada usaha debitur/kegiatan usahanya.

\section{Ukuran Perusahaan}

Menurut Brigham \& Houston (2010:4) Ukuran perusahaan merupakan ukuran besar kecilnya sebuah perusahaan yang ditunjukan atau dinilai oleh total aset, total penjualan, jumlah laba, beban pajak dan lain-lain. Ukuran perusahaan dinilai melalui total aset yang dimiliki perusahaan. Kecil besarnya perusahaan dapat mencerminkan bahwa perusahaan tersebut dapat mengelola SDA yang dimiliki dengan semaksimal mungkin. Ukuran bank merupakan salah satu faktor yang menentukan tingkat kepercayaan investor menanamkan dananya kepada pengelola modal.

Ukuran bank menurut Masita dan Imam (2014) merupakan salah satu karakteristik bank yang umumnya menjadi determinan dari efisiensi perbankan. Bank berukuran besar umumnya memiliki keunggulan dari pada bank berukuran sedang atau kecil, seperti jumlah modal yang lebih besar, jumlah tenaga kerja dan reputasi yang lebih baik, dan kemampuan untuk menghasilkan pendapatan non- bunga dari sumber lain seperti jasa investasi perbankan, jasa transfer uang, jasa penukaran mata uang asing dan jasa asuransi.

Hal ini akan memudahkan bank berukuran besar untuk memperoleh pinjaman daripada bank berukuran sedang dan kecil. Semakin besar ukuran bank maka bank tersebut memiliki lebih banyak modal yang dapat digunakan untuk mengadopsi teknologi.

\section{Metode Penelitian}

Penelitian ini merupakan pengujian hipotesis yang bertujuan untuk menguji pengaruh BOPO, Non Performing Financing, dan Ukuran Perusahaan terhadap tingkat efisiensi perbankan syariah di indonesia. Sumber data yang digunakan adalah data sekunder yaitu berupa laporan tahunan (annual report) dan laporan keuangan.Teknik analisis data menggunakan analisis regresi linear berganda. Persamaan model empiris yang digunakan yaitu:

$$
\mathrm{Y}=\alpha+\beta 1 \mathrm{X} 1+\beta 2 \mathrm{X} 2+\beta 3 \mathrm{X} 3+\mathrm{e}
$$

Dimana $\mathrm{Y}$ adalah tingkat efisiensi, $\alpha$ adalah
Konstanta, $\beta 1, \beta 2$, dan $\beta 3$ adalah Koefisien Regresi, $\mathrm{X} 1$ adalah BOPO, X2 adalah Non Performing Financing, X3 adalah Ukuran Perusahaan, dan e adalah Error.

\section{Hasil Penelitian dan Pembahasan}

\section{Hasil Penelitian}

\section{Uji Normalitas Data}

Uji normalitas digunakan untuk menguji apakah dalam model regresi variabel terikat dan variabel bebas keduanya mempunyai distribusi normal atau tidak (Ghozali (2013). Dalam penelitian ini uji normalitas data dilakukan dengan menggunakan Kolmograf-Smirnov Test.Hasil pengujian normalitas dapat dilihat pada tabel 4.1.

Tabel 4.1

One-Sample Kolmogorov-Smirnov Test

\begin{tabular}{|lrr|}
\hline & & $\begin{array}{c}\text { Unstandardized } \\
\text { Residual }\end{array}$ \\
\hline $\mathbf{N}$ & & 51 \\
Normal & Mean & -10.0982221 \\
Parameters ${ }^{\mathrm{a}, \mathrm{b}}$ & $\quad$ Std. Deviation & 41.3151761 \\
Most Extreme & Absolute & .120 \\
& & .084 \\
Negative Kolmogorov-Smirnov Z & -.120 \\
Asymp. Sig. (2-tailed) & .120 \\
& &, 065 \\
\hline
\end{tabular}

Sumber: Output SPSS (2019)

Berdasarkan Tabel 4.1 menunjukkan bahwa nilai Asymp. Sig. (2-tailed) berdistribusi normal karena nilai Asymp. Sig. (2-tailed) 0,065 > 0,05 sehingga penelitian dapat digunakan.

\section{Uji Multikolonieritas}

Uji multikolinearitas digunakan untuk menguji apakah pada model regresi ditemukan adanya korelasi antar variabel independen. Pada model regresi yang baik, seharusnya tidak terdapat korelasi antar variabel independen. Ghozali (2013) mengatakan bahwa cara yang dapat digunakan untuk menguji ada tidaknya korelasi antar variabel independen ialah dengan melihat nilai tolerance dan lawannya, Variance Inflaction Factor (VIF). Kedua ukuran ini menunjukkan setiap variabel independen manakah yang dijelaskan oleh variabel lainnya. Nilai yang dipakai untuk menunjukkan adanya 
multikolonieritas ialah nilai tolerance $\leq 0,10$ atau sama dengan nilai VIF $\geq 10$. Hasil pengujian multikolonieritas dapat dilihat pada tabel 4.2.

Tabel 4.2

Hasil Uji Multikolonieritas

\begin{tabular}{|l|c|c|}
\multicolumn{2}{c}{ Coefficients $^{\mathbf{a}}$} \\
\hline \multirow{2}{*}{ Model } & \multicolumn{2}{|c|}{ Collinearity Statistics } \\
\cline { 2 - 3 } (Constant) BOPO & Tolerance & VIF \\
\cline { 2 - 3 } NPF & & \\
\cline { 2 - 3 } Total Aset & .629 & 1.589 \\
\cline { 2 - 3 } & .643 & 1.554 \\
\cline { 2 - 3 } & .965 & 1.037 \\
\hline
\end{tabular}

a. Dependent Variable: Efisiensi

Berdasarkan tabel output "Coefficients" diketahui bahwa nilai Tolerance untuk variabel BOPO (X1) sebesar 0,629, variabel NPF (X2) sebesar 0,6443, dan variabel Total Aset (X3) sebesar 0,965 lebih besar dari 0,10. Sementara, nilai VIF untuk variabel BOPO (X1) sebesar 1,589, variabel NPF (X2) sebesar 1,554, dan variabel Total Aset (X3) sebesar 1,037 lebih kecil dari 10,00. Maka mengacu pada dasar pengambilan keputusan dalam uji multikolinearitas dapat disimpulkan bahwa tidak terjadi gejala multikolinearitas dalam model regresi.

\section{Uji Heterokedastisitas}

Uji heteroskedastisitas bertujuan untuk menguji apakah dalam model regresi terjadi ketidaksamaan varian dari satu pengamatan ke pengamatan yang lain. Jika varian dari residual satu pengamatan ke pengamatan lain tetap, maka disebut homoskedastisitas dan jika berbeda disebut heteroskedastisitas Ghozali (2013). Model regresi yang baik ialah yang tidak muncul heteroskedastisitas.

Tabel 4.3

Hasil Uji Heterokedastisitas

\begin{tabular}{|c|c|c|c|}
\hline Keterangan & Model 1 & Model 2 & Model 3 \\
\hline Nilai Signifikansi & 0.730 & 0,999 & 0,681 \\
\hline
\end{tabular}

Sumber: Data diolah (2019)

Dari output diatas diketahui bahwa nilai signifikansi atau Sig. (2-tailed) variabel BOPO
(X1) sebesar 0,730, variabel NPF (X2) sebesar 0,999 dan variabel Total Aset sebesar 0,681. Karena nilai ketiga variabel independen (X) lebih besar dari 0,05 sehingga dapat disimpulkan bahwa tidak terdapat gejala heteroskedastitas. Artinya model regresi yang dipakai untuk penelitian ini layak untuk dilakukan.

\section{Uji Autokorelasi}

Uji autokolerasi memiliki tujuan untuk menguji apakah dalam suatu model regresi linear terdapat korelasi antara kesalahan pengganggu pada periode $\mathrm{t}$ dengan kesalahan pengganggu pada periode t-1 (sebelumnya) dengan menggunakan uji Durbin- Watson (Ghozali (2013).

Tabel 4.4

Hasil Uji Autokorelasi

\begin{tabular}{|l|c|r|r|r|r|}
\hline Model & $\mathrm{R}$ & $\begin{array}{c}\mathrm{R} \\
\text { Square }\end{array}$ & $\begin{array}{c}\text { Adjusted } \\
\text { R Square }\end{array}$ & $\begin{array}{c}\text { Std. Error } \\
\text { of the } \\
\text { Estimate }\end{array}$ & $\begin{array}{r}\text { Durbin- } \\
\text { Watson }\end{array}$ \\
\hline 1 & $.327^{\mathrm{a}}$ & .107 & .052 & 16.04610 & 2.076 \\
\hline
\end{tabular}

Sumber: Data diolah (2019)

Berdasarkan hasil uji autokorelasi diatas, diketahui bahwa nilai Durbin Watson (d) sebesar 2,076 lebih besar dari batas atas (dU) yakni 1,6815 dan kurang dari (4-dU) 4-1,6815 = 2,3185. Maka sebagaimana dasar pengambilan keputusan dalam uji durbin watson, dapat disimpulkan bahwa tidak terdapat masalah atau gejala autokorelasi. Dengan demikian maka analisis regresi linear berganda untuk uji hipotesis penelitian dapat dilanjutkan.

\section{Signifikansi Simultan (Uji Statistik F)}

Uji statistik $F$ pada dasarnya menunjukkan apakah semua variabel bebas yang dimasukkan dalam model mempunyai pengaruh secara bersama-sama terhadap variabel dependen Ghozali (2013;98). Hasil Uji F dapat dilihat pada table 4.5.

Dari output diatas diketahui bahwa nilai signifikansi atau Sig. (2-tailed) variabel BOPO (X1) 
Tabel 4.5

Hasil Uji Statistik F

\begin{tabular}{|c|c|c|c|c|c|}
\hline \multicolumn{6}{|c|}{ ANOVA $^{\mathrm{a}}$} \\
\hline Model & Sum of Squares & Dr & Mean Square & $\mathrm{F}$ & Sig. \\
\hline Regression & 1512.767 & 3 & 504.256 & 1.958 & $.023^{b}$ \\
\hline 1 Residual & 12616.394 & 49 & 257.477 & & \\
\hline Total & 14129.161 & 52 & & & \\
\hline
\end{tabular}

Sumber: Data diolah (2019)

Berdasarkan tabel output SPSS diatas, diketahi nilai Sig. Adalah sebesar 0,011. Karena nilai Sig. $0,023<0,05$, maka sesuai dengan dasar pengambilan keputusan dalam uji $F$ dapat disimpulkan bahwa hipotesis diterima, atau dengan kata lain BOPO (X1), NPF (X2), dan Total Aset (X3) secara simultan berpengaruh terhadap Efisiensi (Y).

\section{Uji Signifikansi Individual (Uji Statistik t)}

\section{Tabel 4.6}

Hasil Uji Statistik t

\begin{tabular}{|c|c|c|c|c|c|c|}
\hline \multicolumn{7}{|c|}{ Coefficients $^{a}$} \\
\hline & \multirow[t]{2}{*}{ Model } & \multicolumn{2}{|c|}{$\begin{array}{l}\text { Unstandardized } \\
\text { Coefficients }\end{array}$} & \multirow{2}{*}{$\begin{array}{c}\begin{array}{c}\text { Standa rdized } \\
\text { Coefficients }\end{array} \\
\text { Beta }\end{array}$} & \multirow[t]{2}{*}{$\mathrm{t}$} & \multirow[t]{2}{*}{ Sig } \\
\hline & & $B$ & Std. Error & & & \\
\hline \multirow[t]{4}{*}{1} & (Const ant) & 502.331 & 339.498 & & 1.48 & .145 \\
\hline & BOPO & -48.860 & 73.728 & -.105 & -.663 & .511 \\
\hline & NPF & 8.716 & 14.534 & .094 & .600 & .551 \\
\hline & ASET & -22.517 & 6.139 & -.471 & -3.66 & .001 \\
\hline
\end{tabular}

Sumber: Data diolah (2019)

Hasil Pengujian menunjukkan sebagai berikut :

1. Variabel BOPO (X1) memiliki nilai beta yaitu sebesar -48.860 dengan koefisien negatif yang berarti berpengaruh secara positif terhadap tingkat efisiensi. Kemudian menunjukan nilai $\mathrm{t}$ sebesar -0,663 dengan signifikansi sebesar 0.511. Nilai signifikansi tersebut lebih besar dari 0,05. Hal ini berarti bahwa BOPO (X1) tidak memiliki pengaruh terhadap efisiensi bank syariah.

2. Variabel NPF (X2) memiliki nilai beta yaitu sebesar sebesar 8.716 dengan koefisien negatif yang berarti berpengaruh secara negaif terhadap tingkat efisiensi. Kemudian menunjukan nilai $\mathrm{t}$ sebesar 0,600 dengan signifikansi sebesar
Pengujian hipotesis uji t dilakukan untuk menyelidiki lebih lajut manakah diantara tiga variabel independen yang berpengaruh signifikan terhadap tingkat efisiensi. Uji statistik $\mathrm{t}$ dilakukan dengan melihat nilai signifikansi yang diperoleh masing- masing variabel. Hasil Uji $t$ dapat dilihat pada table 4.6. 
perbankan syariah.

\section{Uji Koefisien Determinasi $\left(\mathbf{R}^{\mathbf{2}}\right)$}

Koefisien determinasi $\left(\mathrm{R}^{2}\right)$ mengukur besarnya persentase variasi variabel dependen yang dapat dijelaskan oleh variabel independen. Nilai koefisien determinasi ialah antara nol dan satu. Nilai $R^{2}$ yang kecil berarti bahwa kemampuan variabel independen dalam menerangkan variabel dependen sangat terbatas (Ghozali (2013). Nilai yang mendekati satu berarti bahwa variabel independen memberikan hampir semua informasi yang dibutuhkan untuk memprediksi variasi variabel dependen. Hasil Uji $\mathrm{R}^{2}$ dapat dilihat pada table 4.7 .

Tabel 4.7

Hasil Uji Koefisien Determinasi $\left(\mathbf{R}^{2}\right)$

\begin{tabular}{|c|c|c|c|c|}
\hline Model & $\mathrm{R}$ & $\begin{array}{c}\mathrm{R} \\
\text { Square }\end{array}$ & $\begin{array}{c}\text { Adjusted } \\
\mathrm{R} \text { Square }\end{array}$ & $\begin{array}{c}\text { Std. Error of the } \\
\text { Estimate }\end{array}$ \\
\hline 1 & $.471^{\mathrm{a}}$ &, 221 & .174 & 89.2478 \\
\hline
\end{tabular}

Berdasarkan tabel output SPSS "Model Summary" diatas, diketahui nilai koefisien determinasi (Adjusted R Square) adalah sebesar 0,174 atau sama dengan $15,2 \%$. Angka tersebut mengandung arti bahwa variabel BOPO (X1), NPF (X2) dan Total Aset (X3) secara bersama-sama berpengaruh terhadap variabel Efisiensi (Y) sebesar $17,4 \%$. Sedangkan sisanya dipengaruhi oleh variabel lain diluar persamaan regresi ini atau variabel yang tidak diteliti.

\section{Pembahasan Hasil Penelitian}

\section{Pengaruh BOPO, Non Performing Financing dan} ukuran perusahaan terhadap tingkat efisiensi

Berdasarkan hasil pengujian statistik $\mathrm{F}$ diperoleh nilai signifikansi sebesar 0,023 yang berarti bahwa variabel independen, yaitu BOPO ,Non Performing Financing dan ukuran perusahaan secara simultan berpengaruh terhadap variabel dependen, yaitu tingkat efisiensi perbankan syariah di Indonesia tahun 2014-2018, sehingga dapat disimpulkan bahwa hipotesis pertama (H1) diterima.

\section{Pengaruh BOPO terhadap tingkat efisiensi}

Berdasarkan hasil pengujian statistik dengan uji t menunjukkan bahwa variabel BOPO sebesar $-48,, 860$ dengan koefisien negatif yang berarti berpengaruh secara negatif terhadap tingkat efisiensi. Kemudian menunjukan nilai $\mathrm{t}$ sebesar 0,663 dengan signifikansi sebesar 0.551. Nilai signifikansi tersebut lebih besar dari 0,05. Hal ini berarti bahwa BOPO tidak memiliki pengaruh terhadap efisiensi bank syariah. Penelitian ini sejalan dengan penelitian yang dilakukan oleh (Fitri fadilah \& Indri Yuliafitri, 2018) yang menyimpulkan bahwa BOPO tidak berpengaruh terhadap tingkat efisiensi bank syariah.

\section{Pengaruh Non Performing Financing terhadap tingkat efisiensi}

Berdasarkan hasil pengujian statistik dengan uji t dapat dilihat bahwa variabel NPF sebesar 8,716 dengan koefisien positif yang berarti berpengaruh secara positif terhadap tingkat efisiensi. Kemudian menunjukan nilai $\mathrm{t}$ sebesar 0,600 dengan signifikansi sebesar 0,551. Nilai signifikansi tersebut jauh lebih besar dari 0,05 . Hal ini berarti bahwa NPF tidak memiliki pengaruh terhadap efisiensi bank syariah. Penemuan ini tidak sejalan dengan penelitian yang dilakukan oleh Nurwulan (2011) yang menyatakan bahwa NPF berpengaruh positif terhadap tingkat efisiensi perbankan.

Hasil penelitian ini sesuai dengan penelitian yang dilakukan oleh Ar- Royyan Ramli \& Abdul Hakim (2017) Menyatakan bahwa NPF berpengaruh negatif dan tidak signifikan terhadap efisiensi bank syariah. Apabila bank tidak mampu mengelola pinjaman atau pembiayaan maka akan berpengaruh terhadap NPF yang nantinya akan berpengaruh terhadap tingkat efisiensi.

\section{Pengaruh ukuran perusahaan terhadap tingkat efisiensi}

Berdasarkan hasil pengujian statistik dengan uji t dapat dilihat bahwa variabel Total Aset sebesar 22.517 dengan koefisien negatif yang berarti berpengaruh secara positif terhadap tingkat efisiensi. Kemudian menunjukan nilai $\mathrm{t}$ sebesar 3,668 dengan signifikansi sebesar 0.001. Nilai signifikansi tersebut jauh lebih kecil dari signifikansi 
$5 \%$ atau 0,05. Hal ini berarti bahwa Total Aset memiliki pengaruh terhadap efisiensi bank syariah.

Dengan ukuran perbankan yang lebih besar dan memiliki keunggulan salah satunya modal yang lebih besar tentunya relatif akan menghasilkan profit yang lebih besar pula, dimana nantinya tingkat profitabilitas ini akan berpengaruh terhadap tingkat efisiensi suatu perbankan. Penelitian ini sejalan dengan penelitian yang dilakukan oleh Nurwulan (2011) yang menyimpulkan bahwa ukuran bank berpengaruh positif signifikan terhadap variabel efisiensi bank. Penemuan ini tidak sejalan dengan penelitian Fafa Yushifa (2015) yang menyatakan bahwa ukuran perusahaan berpengaruh secara positif dan tidak memiliki pengaruh yang signifikan terhadap tingkat efisiensi bank syariah.

\section{Kesimpulan, Keterbatasan dan Saran}

Berdasarkan hasil penelitian yang dilakukan, maka dapat disimpulkan bahwa, secara simultan BOPO, Non Performing Financing, dan Ukuran Perusahaan berpengaruh terhadap tingkat efisiensi perbankan syariah di Indonesia tahun 2014-2018. Secara parsial BOPO tidak berpengaruh terhadap tingkat efisiensi perbankan syariah di Indonesia. Non performing financing tidak berpengaruh terhadap tingkat efisiensi perbankan syariah di Indonesia. Dan Ukur an $\mathrm{P}$ erusahaan berpengaruh terhadaptingkat efisiensi perbankan syariah di Indonesia.

Keterbatasan penelitian ini, variabel independen dalam penelitian ini hanya melibatkan 3 faktor saja, hal ini mengakibatkan terbaikannya fakor-faktor lain yang mempengaruhi tingkat efisiensi perbankan syariah.

Saran-saran untuk penelitian selanjutnya yaitu untuk menambahkan beberapa variabel lainnya seperti variabel non keuangan diduga mempengaruhi tingkat efisiensi perbankan syariah di Indonesia.

\section{Daftar Pustaka}

Alqur'an Al Karim.

Abdaliah, \& Ikhsan, A. E. (2018). Pengaruh tingkat bagi hasil, tingkat suku bunga, jumlah kantor, dan ukuran bank terhadap jumlah deposito mudharabah pada perbankan syariah. Jurnal Ilmiah Mahasiswa Ekonomi Akuntansi (JIMEKA), 3(4), 538-551.

Abdullah, Faisal. (2003). Manajemen Perbankan (Teknik Analisis Kinerja Keuangan Bank). Malang: Universitas Muhammadiyah Malang (UMM) Press.

Abidin, Z., \& Endri. (2009). Kinerja Efisiensi Teknis Bank Pembangunan Daerah: Pendekatan Data Envelopment Analysis (DEA). Jurnal Akuntansi Dan Keuangan, 11, 21-29. https://doi.org/10.9744/jak.11.1.pp. 21$\underline{29}$

Amalia, \& Meutia, F. (2018). Analisis perbandingan efisiensi bank umum konvensional dan bank umum syariah di indonesia dengan menggunakan metode data envelopment analysis. Jurnal Ilmiah Mahasiswa Ekonomi Akuntansi (JIMEKA), 3(3), 342-352.

Arif, I. (2010). Analisis Perbandingan Efisiensi Perbankan Syariah Menggunakan Metode Data Envelopment Analysis (DEA) (Periode 2006-2009). Skripsi. Universitas Islam Indonesia. Yogyakarta.

Ario. (2005). Analisis Perbandingan Efisiensi Bank Persero dan Bank Asing Menggunakan Metode Data Envelopment Analysis (periode Tahun 2000-2003).

As, Mahmoedin. (2010). Melacak Kredit Bermasalah. Cetakan Pertama. Jakarta: Pustaka Sinar Harapan.

Brigham dan Houston.(2010). Dasar-dasar Manajemen Keuangan (edisi III). Jakarta : Salemba Empat. Dendawijaya, Lukman. (2009). Manajemen Perbankan. Jakarta: Ghalia Indonesia.

Fadilah, F., \& Yuliafitri, I. (2018). Analisis Efisiensi Bank Umum Syariah Hasil Pemisahan Dan Non Pemisahan Serta FaktorFaktor Yang Mempengaruhinya (Studi Pada Bank Umum Syariah Yang Terdaftar Di Otoritas Jasa Keuangan Pada Periode 20112016). ISLAMICONOMIC: Jurnal Ekonomi Islam, 9(1). 
https://doi.org/10.32678/ijei.v9i1.88.

Firdaus, M. F., \& Hosen, M. N. (2013). Efisiensi Bank Umum Syariah Menggunakan Pendekatan Two- Stage Data Envelopment Analysis. Bulletin Ekonomi Moneter Dan Perbankan, 16, 167-188.

Firmansari, D., \& Suprayogi, N. (2015). Pengaruh Variabel Makroekonomi dan Variabel Spesifik Bank Terhadap Non Performing Financing Pada Bank.

Ghozali, Imam. (2013). Aplikasi Analisis Multivariate dengan Program IBM SPSS 21. Semarang: Undip.

Gujarati, D. N. (2003). Basic Econometrics. FourthEdition. NewYork: McGraw Hill. Hidayat, R. (2011). Kajian Efisiensi Perbankan Syariah Di Indonesia (Pendekatan Data Envelopment Analysis). Media Riset Bisnis Dan Manajemen.

Indriantoro, Nur., dan Supomo, Bambang. (2013). Metodologi Penelitian Bisnis Untuk Akuntansi \& Manajemen. Yogyakarta: BPFE.

Masita, Gracia; Subekti, Imam. (2014). Determinan Efisiensi Perbankan Di Indonesia Berdasarkan Data Envelopment Analyis (DEA).Jurnal Ilmiah Mahasiswa FEB,

Mudjarat, Kuncoro \& Suharjonoo (2002). Manajemen Perbankan. Yogyakarta: BPFE.

Muharam, H., \& Rizki Pusvitasari. (2005). Analisis Perbandingan Efisiensi Bank Syariah di Indonesia Dengan Metode Data Envelopment Analysis, II(3), 80-116. Retrieved from http://eprints.undip.ac.id/38915/.

Nugroho, R. A., \& Muharam, H. (2009). Analisis Perbandingan Efisiensi Bank Umum Syariah (BUS) dan Unit Usaha Syariah (UUS) dengan Metode Stochastic Frontier Analysis (Periode 2005-2009).

Nurwulan. (2011). Analisis pengaruh bank size, npl, roa, kapitalisasi, dan car terhadap efisiensi perbankan. 1-26.

OJK. (2017). Statistik Perbankan Syariah Januari 2017. Retrieved March 17, 2017, from www.ojk.go.id

OJK. No.15/POJK.03/2017 tentang Penetapan Status dan Tindak Lanjut Pengawasan Bank Umum. Diakses 1 Agustus 2019

Padmantyo, S. (2011). Analisis Manajemen Laba Pada Laporan Keuangan Perbankan Syariah. Jurnal Manajemen Dan Bisnis, 46-70.

Permana, F. Y., \& Adityawarman. (2015). Analisis Faktor-Faktor yang Mempengaruhi Tingkat Efisiensi Perankan Syariah di Indonesia. Diponegoro Journal of Accounting, 4, 1-14. Retrieved from http://ejournals1.undip.ac.id/index.php/accounting.

Permono, \& Darmawan. (2000). Analisis Efisiensi Industri Perbankan Di Indonesia (Studi Kasus Bank-Bank Devisa di Indonesia Tahun $1991-$

1996). Jurnal Ekonomi Dan Bisnis Indonesia

2000, XV(1). Retrieved from http://ilib.ugm.ac.id/jurnal/detail.php?dataId=9433.

Purnamasari, Diah Ayu dan Astri Fitria. (2015). Pengaruh Perputaran Piutang dan Ukuran Perusahaan Terhadap Profitabilitas Perusahaan Kimia. Jurnal Ilmu dan Riset Akuntansi. Volume 4. Nomor 8.

Ramly, A. R., \& Hakim, A. (2017). Pemodelan Efisiensi Bank di Indonesia: Perbandingan antara Bank Syariah dan Bank Konvensional. Bismis Dan Manajemen, 7(April), 131-148.

Sekaran, Uma. (2014). Metodologi Penelitian untuk Bisnis (Research Methods for Business). Buku 1 Edisi 4. Jakrta: Salemba Empat.

Sekaran, Uma., \& Bougie. R. (2013) Research Methods for Business: A SkillBuilding Approach. Sixth Edition. USA: Wiley.

Septiana, N. (2015). Faktor-Faktor yang Mempengaruhi Efisiensi Perbankan di Indonesia (Studi pada Bank Umum Konvensional dan Syariah). Derivatif, 9(2), 72-84.

Siamat, Dahlan. (2005). Manajemen Lembaga 
Keuangan. Jakarta: Lembaga Penerbit Fakultas Ekonomi Universitas Indonesia.

Sihombing, N. H., \& Yahya, M. R. (2016).

BEBAN OPERASIONAL PENDAPATAN

OPERASIONAL ( BOPO ), DANA

PIHAK KETIGA. Jurnal Ilmiah

Mahasiswa Ekonomi Akuntansi (JIMEKA), 1(2), 127-137.

Sutawijaya, A., \& Lestari, E. P. (2009). Efisiensi Teknik Perbankan Indonesia Pascakrisis Ekonomi: Sebuah Studi Empiris Penerapan Model Dea. Jurnal Ekonomi Pembangunan: Kajian Masalah Ekonomi Dan Pembangunan,

10(1), 49. https://doi.org/10.23917/jep.v10i1.808. Wahab. (2015). Economica: jurnal pemikiran dan penelitian ekonomi Islam. Economica: Jurnal Ekonomi Islam, 6(2), 57-76. Retrieved from http://journal.walisongo.ac.id/index.php/econo mica/article/view/794/704.

Wiroso, (2005), Penghimpunan Dana dan Distribusi Hasil Usaha Bank Syariah, Jakarta : Gramedia Widiasarana.

https://keuangan.kontan.co.id/news/lebih-efisien-

bopo- bank-syariah-stabil-di-tahun-lalu https://keuangan.kontan.co.id/news/npf-banksyariah-membaik-di-tahun-lalu. https://www.ojk.go.id/id/kanal/syariah/tentang -syariah/Pages/Perbankan-Syariah.aspx https://www.republika.co.id/berita/ekonomi/sy ariah-ekonomi/18/12/11/pjisqj383-ojk-inginada-bank-syariah-yang-naik-kelas-ke-buku-4. 